\title{
KONTRIBUSI USAHATANI JERUK SIAM (CITRUS NOBILIS L. VAR. MICROCARPA HASSK) TERHADAP PENDAPATAN RUMAH TANGGA PETANI DI KECAMATAN KAMANG MAGEK KABUPATEN AGAM
}

\section{The Contribution of Citrus (Citrus Nobilis L. Var. Microcarpa Hassk) Toward Household Incomes at Farmers Group District of Kamang Magek, Regency Of Agam}

\author{
Meriyanti $^{1,}$ Hasnah $^{2}$, Rusda Khairati ${ }^{3}$ \\ ${ }^{1}$ Mahasiswa Program Studi Agribisnis Fakultas Pertanian Universitas Andalas, Padang \\ ${ }^{2}$ Staff Pengajar Program Studi Agribisnis Fakultas Pertanian Universitas Andalas, Padang \\ ${ }^{3}$ Staff Pengajar Program Studi Agribisnis Fakultas Pertanian Universitas Andalas, Padang \\ *email koresponden: zizimeriyanti@gmail.com
}

\begin{abstract}
Abstrak
Jeruk merupakan tanaman buah yang banyak terdapat di Sumatera Barat terutama di Kabupaten Agam, yang sekaligus sebagai daerah penghasil jeruk terbesar yaitu sebanyak 52.561,00 ton pada tahun 2016. Kamang Magek merupakan salah satu Kecamatan penghasil jeruk terbesar di Kabupaten Agam. Tujuan penelitian ini (1) mendeskripsikan profil usahatani Jeruk Siam (2) menganalisa kontribusi usahatani Jeruk Siam terhadap pendapatan rumah tangga. Metode yang digunakan adalah survey. Teknik pengambilan responden yaitu dengan purposive (sengaja). Data dianalisa secara deskriptif kualitatif untuk tujuan pertama, secara deskriptif kuantitatif untuk tujuan kedua. Hasil penelitian tentang kontribusi usahatani jeruk siam terhadap pendapatan rumah tangga petani menunjukkan bahwa sumber pendapatan rumah tangga petani berasal dari penanaman jeruk siam, selain itu juga berasal dari pertanian lainnya dan non pertanian. Besar rata-rata kontribusi jeruk siam yang diberikan selama satu tahun yaitu 53.2\% atau Rp.27.277.678,-. Disimpulkan bahwa usahatani jeruk siam memiliki kontribusi yang besar terhadap pendapatan rumah tangga petani. Jadi Usahatani jeruk siam ini sangat bagus untuk dikembangkan ke depannya. Pemanfaatan lahan yang optimal dengan tetap memperhatikan keseimbangan liungkungan akan dapat memberikan hasil yang optimal.
\end{abstract}

Kata kunci: Kontribusi, usahatani jeruk siam, pendapatan rumah tangga

\begin{abstract}
Citrus is a fruit plant that is widely found in West Sumatra, especially in Agam Regency, which is also the largest citrus producing area by producing 52,561.00 tons in 2016. Kamang Magek is one of the largest citrus producing districts in Agam Regency. The purpose of this research (1) describes the profile of citrus nobilis farming (2) analyzes the contribution of citrus nobilis farming to household income. The method used is survey. The respondents' taking technique is by purposive. Data is analyzed with qualitative descriptive for the first purpose, quantitative descriptive for the second purpose. The results of the research on the contribution of citrus nobilis farming to the income of farmer households indicates that the source of income of farmer households comes from planting citrus nobilis, then agriculture and nonagricultural. The average contribution of income from citrus nobilis for a year reaches $53.2 \%$ or Rp.27.277.678,-. It was concluded that citrus nobilis farming has a large contribution to the income of farmer households. So this citrus nobilis farming is very good for future development. Optimal use of land while paying attention to the balance of environment will be able to provide optimal result.
\end{abstract}

Keywords: Contribution, citrus siam farming, household income 


\section{PENDAHULUAN}

\section{Latar Belakang}

Pembangunan sektor pertanian identik dengan pembangunan ekonomi secara nasional dan identik dengan pendekatan dalam sistim agribisnis. Agribisnis semakin dirasakan oleh pelaku ekonomi di Indonesia karena agribisnis mampu menjadikan lapangan usaha sekaligus kesempatan kerja baik di perkotaan atau dipedesaan. Salah satu subsektor pertanian yang memberikan kontribusi terhadap produk domestik bruto adalah subsektor hortikultura (Purnama, 2009). Hortikultura adalah komoditas yang memiliki masa depan sangat cerah dari keunggulan kompetitif dan komparatif yang dimilikinya dalam pemulihan perekonomian Indonesia di waktu mendatang. Buah jeruk merupakan salah satu tanaman hortikultura yang banyak dibudidayakan di Indonesia. Pengembangan hortikultura di Indonesia pada umumnya masih dalam skala perkebunan rakyat yang tumbuh dan dipelihara secara alami dan tradisional, sedangkan jenis komoditas hortikultura yang diusahakan masih terbatas (Pratama, 2010)

Jenis jeruk yang paling banyak dikembangkan dan yang paling luas penyebarannya di Indonesia adalah jeruk siam (Citrus nobilis). Tanaman Jeruk memiliki nilai ekonomi yang tinggi, rasa buah yang enak dan merupakan bahan pelengkap utama dalam menunjang gizi masyarakat. Selain rasanya menyegarkan buah jeruk juga banyak mengandung vitamin $\mathrm{C}$ dan $\mathrm{A}$, antioksidan, kalium dan kandungan gizi lainnya (Soedarya , 2009)

Sumatera Barat merupakan salah satu provinsi di Indonesia yang membudidayakan Jeruk. Daerah penghasil jeruk di Sumatera Barat diantaranya terdapat di Kabupaten 50 Kota, Pasaman, Agam, Padang Pariaman, Solok dan Solok Selatan. Kabupaten Agam merupakan suatu daerah yang memiliki keunggulan tanaman holtikultura jeruk dengan tingkat produksi jeruk terbesar di Sumatera Barat.Menurut data Luas Area Jeruk dan produksi Jeruk pada tahun 2016 di Kabupaten Agam terlihat bahwa dari tahun 2012 hingga tahun 2016 terjadi peningkatan luas panen tanaman Jeruk di Kabupaten Agam dimana pada Tahun 2016 kecamatan Kamang Magek memiliki luas panen nomor 3 terbesar setelah Kecamatan Baso dan Palupuh (BPS, 2017)

Kecamatan Kamang Magek memilki 3 Nagari yaitu Nagari Kamang Hilia, Nagari Kamang Mudiak dan Nagari Magek dimana tingkat produktivitas tanaman Jeruk Siam kamang yang paling tinggi berada di Nagari Kamang Hilia. Di Kecamatan Kamang Magek pertanian jeruk siam sempat punah tahun 1980-an karena terserang penyakit CVPD. Namun semenjak tahun 2006, beberapa kelompok warga mulai mencoba kembali untuk bertanam Jeruk Siam. Pengembangan ini juga di dukung oleh program pemerintah setempat dalam mengembangkan jeruk di kawasan Kamang. Petani jeruk yang sebelumnya trauma akibat penyakit yang menyerang tanaman Jeruk Siam kamang, secara perlahan mulai menanam kembali jeruk jenis siam dihalaman dan dikebun serta terus intensif sejak beberapa tahun terakhir. Bangkitnya Jeruk Siam kamang ini sudah banyak menarik petani lain untuk ikut mengembangkan kembali kejayaan Jeruk Siam kamang pada masa lalu sebab untuk saat ini jeruk tersebut sudah menembus pasar-pasar di Sumatera Barat.

\section{Tujuan}

1. Mendeskripsikan profil usahatani Jeruk Siam di Kecamatan Kamang Magek Kabupaten Agam.

2. Menganalisa kontribusi usaha tani Jeruk Siam terhadap pendapatan rumah tangga petani Jeruk Siam di Kecamatan Kamang Magek Kabupaten Agam

\section{METODE PENELITIAN}

\section{Tempat dan Waktu Penelitian}

Penelitian ini dilaksanakan pada usahatani jeruk siam di Kecamatan Kamang Magek, Kabupaten Agam. Daerah ini di pilih secara sengaja (purposive) dengan pertimbangan Jeruk Siam Kamang menempati posisi produksi jeruk terbesar ketiga setelah Baso dan Palupuah. 


\section{Metode Penelitian}

Metode yang digunakan dalam penelitian ini adalah metode survei. Dalam penelitian ini metode survei digunakan untuk pengamatan, penyelidikan dan memperoleh fakta dan keterangan di lapangan secara langsung terkait dengan kegiatan usahatani perkebunan jeruk, pendapatan total yang diperoleh dalam usaha perkebunan jeruk, pendapatan di luar usahatani jeruk baik usahatani selain jeruk maupun non-usahatani, serta kontribusinya terhadap pendapatan yang diperoleh petani dalam melakukan usaha perkebunan jeruk di lokasi penelitian.

\section{Responden Penelitian}

Responden dalam penelitian ini adalah petani jeruk siam yang berada di Kecamatan Kamang Magek khususnya 2 nagari penghasil jeruk terbesar yaitu Nagari Kamang Hilir dan Nagari Kamang Mudik. Pengambilan responden di ambil secara purposive dengan jumlah 27 petani dengan pembagian 12 dari Kamang Hilia dan 15 dari Kamang Mudik.

\section{Metode Pengumpulan Data}

Sumber data dalam penelitian ini adalah data primer dan data sekunder. Metode yang digunakan dalam penelitian ini teridiri dari wawancara, observasi, studi kepustakaan dan quisioner.

\section{HASIL DAN PEMBAHASAN}

Tanaman jeruk di Kecamatan Kamang Magek merupakan tanaman yang telah berkembang sejak lama, bahkan tanaman ini telah dibudidayakan oleh penduduk untuk tujuan komersil. Salah satu faktor pendukung tanaman jeruk mudah di budidayakan didaerah ini adalah faktor agroklimatnya yang sangat cocok dengan tanaman jeruk seperti iklim, keadaan tanah atau lahan, ketinggian tempat, suhu dan curah hujan. Pada tahun 1980-an tanaman jaruk siam kamang terserang penyakit CVPD yang menyebabkan rusak dan matinya tanaman Jeruk Siam kamang. Karena waktu itu tidak ada obat pembasmi hama tersebut, hasilnya secara perlahan Limau Kamang hilang dipasaran. Namun Pada tahun 2006, beberapa kelompok warga mulai mencoba kembali untuk bertanam jeruk siam. Hasilnya, pada tahun 2013 lalu hingga sekarang, ada beberapa petani yang telah memanen hasil jeruk siam meski hasil panen kali ini tidak sebanyak di era kejayaannya. Pada tahun 2013 lalu, Pemerintah Kecamatan Kamang Magek berupaya untuk mengembalikan era kejayaan itu, dengan mengajak petani kembali bertanam jeruk. Hal yang dilakukan yaitu dengan membagikan bibit gratis kepada masyarakat. Menurut data produksi jeruk siam di Kecamatan Kamang Magek pada tahun 2017 produksi jeruk

Tabel 1. Produksi Jeruk Siam di Kecamatan Kamang Magek

\begin{tabular}{llllll}
\hline No. & Nagari & $\begin{array}{l}\text { Luas Tanam } \\
\text { (Ha) }\end{array}$ & $\begin{array}{l}\text { Tanaman Blm } \\
\text { Menghasilkan(Ha) }\end{array}$ & $\begin{array}{l}\text { Tanaman } \\
\text { Menghasilkan(Ha) }\end{array}$ & $\begin{array}{l}\text { Produksi } \\
\text { (Ton/Ha) }\end{array}$ \\
\hline 1. & Kamang Hilir & 32 & 20 & 12 & 12,00 \\
2. & Kamang Mudiak & 43 & 28 & 15 & 9,00 \\
3. & Magek & 5 & 1 & 4 & 3,20 \\
\hline Jumlah & 80 & 49 & 31 & 24,80 \\
\hline
\end{tabular}

Sumber: UPT BP4K2P Kecamatan Kamang Magek 2016

\section{Variabel Penelitian dan Metode Analisis Data}

Variabel dalam penelitian ini untuk mengetahui profil usahatani, pendapatan total rumah tangga, dan kontribusi jeruk terhadap pendapatan total rumah tangga petani jeruk siam. Data dianalisis dengan menggunakan analisis kuantitatif dan deskriptif. yang dihasilkan yaitu sebesar 24,8 Ton/Ha lengkapnya dapat dilihat pada Tabel 1 .

Dari Tabel diatas dapat kita ketahui bahwa terdapat tiga nagari yang menghasilkan jeruk siam di Kecamatan Kamang Magek diantaranya nagari 
kamang hilir dan kamang mudik menempati produksi dan luas tanam terbesar. lebih jelas mengenai teknik budidaya jeruk siam petani responden dapat dijelaskan sebagai berikut.

\section{Profil Petani Responden}

Tabel 2. Deskripsi Petani Responden di Kecamatan Kamang Magek Kabupaten Agam

\begin{tabular}{lllcr}
\hline No & Karakteristik & kriteria & Jumlah petani & Persentase \\
\hline 1 & Umur petani responden (Tahun) & $15-49$ & 10 & $37.04 \%$ \\
& & $50-64$ & 13 & $48.15 \%$ \\
\multirow{2}{*}{2} & \multirow{2}{*}{ Tingkat Pendidikan } & $>64$ & 4 & $14.81 \%$ \\
& & $<$ SD & 5 & $18.52 \%$ \\
& & SD & 1 & $3.70 \%$ \\
& & SLTP & 9 & $33.33 \%$ \\
& & SLTA & 11 & $40.74 \%$ \\
3 & Pekerjaan Utama & PT & 1 & $3.70 \%$ \\
& & & 21 & $81.48 \%$ \\
4 & Jumlah anggota keluarga (orang) & Petani & 6 & $18.52 \%$ \\
& & $1-4$ & 27 & $100.00 \%$ \\
5 & Lama Berusahatani jeruk siam ( tahun ) & $>4$ & 0 & $0.00 \%$ \\
& & $1-10$ & 19 & $70.37 \%$ \\
\end{tabular}

Identitas responden dalam penelitian ini meliputi beberapa aspek yang dilihat dari nama, usia responden, tingkat pendidikan, jenis kelamin, luas lahan, jumlah tanggungan, status kepemilikan lahan dan pengalaman berusahatani (tahun). Gambaran umum petani responden dapat di lihat pada pada table 2 berikut

\section{Budidaya Usahatani Jeruk Siam}

Kesesuaian teknik bidudaya jeruk siam yang dilakukan petani bisa dilihat dengan membandingkan teknik budidaya jeruk siam yang dilakukan petani dengan Standar Operasional Prosedur (SOP) jeruk siam. diketahui bahwa $46 \%$ teknik budidaya yang dilakukan petani tidak sesuai dengan SOP jeruk siam. Ketidaksesuaian teknik budidaya terjadi pada kegiatan pemupukan, penyiraman, dan penyemprotan untuk pengendalian hama dan penyakit tanaman. Dimana dalam kegiatan pemupukan maupun kegiatan penyemprotan hama dan penyakit tanaman dosis dan frekuensi yang dilakukan petani melebihi batas yang dianjurkan dalam SOP tanaman jeruk siam. Untuk pembahasan

\section{Biaya Produksi Usahatani Jeruk Siam}

Biaya usaha tani adalah semua pengeluaran yang dipergunakan dalam suatu kegiatan usahatani jeruk siam. Biaya produksi meliputi biaya riil tenaga kerja dan biaya riil sarana produksi. Dalam pendapatan usaha tani ada 2 unsur yang digunakan yaitu unsur penerimaan dan pengeluaran dari usaha tani tersebut. Pada Tabel 4 dapat dilihat perhitungan biaya diambil dari biaya rill yang dibayarkan petani dalam usahatani jeruk. Biaya yang dibayarkan dalam aktivitas usahatani jeruk yang dilakukan oleh responden berupa penanaman, pemeliharaan, pemanenan dan lainnya (Gustiyana, 2004)

Rata-rata biaya produksi usahatani jeruk siam selama satu tahun dari bulan November 2017 - Oktober 2018 yaitu Rp21.977.083,- per rumah tangga responden. Biaya produksi ini terdiri dari biaya tenaga kerja luar keluarga, pupuk organik, pupuk buatan (Phosca, Urea,KCL), serta biaya pajak lahan. Rincian rata-rata biaya produksi jeruk siam dapat dilihat di tabel 4. 
Tabel 3. Perbandingan Teknik Budidaya Jeruk Siam oleh Petani Jeruk Siam dengan Anjuran SOP Jeruk Siam

\begin{tabular}{|c|c|c|c|}
\hline \multirow{2}{*}{ No. } & \multirow{2}{*}{ Teknik Budidaya } & \multicolumn{2}{|c|}{ Kesesuaian (Petani) } \\
\hline & & Sesuai & Tidak Sesuai \\
\hline 1 & Persiapan Lahan & 27 & 0 \\
\hline 2 & $\begin{array}{l}\text { Pengolahan Lahan } \\
\text { Jarak Tanan } \\
\text { Pembuatan Lubang Tanam }\end{array}$ & $\begin{array}{l}18 \\
12\end{array}$ & $\begin{array}{l}9 \\
15\end{array}$ \\
\hline 3 & Penanaman & 27 & 0 \\
\hline 4 & $\begin{array}{l}\text { Pemupukan } \\
\text { Dosis } \\
\text { Frekuensi Pemupukan }\end{array}$ & $\begin{array}{l}0 \\
0\end{array}$ & $\begin{array}{l}27 \\
27\end{array}$ \\
\hline 5 & $\begin{array}{l}\text { Pemeliharaan } \\
\text { Penyiraman } \\
\text { Penyiangan } \\
\text { Pemangkasan } \\
\text { Penjarangan Buah } \\
\text { Penyangga Pohon } \\
\text { Penyemprotan Hama Dan Penyakit }\end{array}$ & $\begin{array}{l}0 \\
6 \\
27 \\
20 \\
27 \\
0\end{array}$ & $\begin{array}{l}27 \\
21 \\
0 \\
7 \\
0 \\
27\end{array}$ \\
\hline 6 & Panen dan pascapanen & 27 & 0 \\
\hline & Total & 191 & 160 \\
\hline & Persentase & $54 \%$ & $46 \%$ \\
\hline
\end{tabular}

Tabel 4. Biaya Produksi Usahatani Jeruk Siam Selama 1 Tahun (November 2017 - Oktober 2018) di Kecamatan Kamang Magek

\begin{tabular}{llll}
\hline No. & Biaya Produksi & Rata-rata/tahun & Rata-Rata/Tahun/Ha \\
\hline 1 & Pupuk (Rp) & 8.852 .248 & 24.245 .845 \\
2 & Obat (Rp) & 4.825 .07 & 14.905 .076 \\
3 & Pajak (Rp) & 17.222 & 17.222 \\
4 & Angkut $(\mathrm{Rp})$ & 132.963 & 392.625 \\
5 & TKLK (Rp) & 6.234 .444 & 14.227 .167 \\
\hline & Total Biaya (Rp) & $\mathbf{2 0 . 0 6 1 . 9 5 2}$ & $\mathbf{5 3 . 7 8 7 . 9 3 5}$ \\
\hline
\end{tabular}

\section{Penerimaan Dan Pendapatan Usahatani Jeruk Siam}

Pendapatan merupakan selisih antara penerimaan dan biaya usahatani. Pendapatan pertanian, meliputi penerimaan dari usahatani jeruk, usahatani selain jeruk, kegiatan berburuh dan lainnya. Menurut (Soekartawi, 2006) penerimaan usaha tani adalah perkalian antara produksi dengan harga jual produk. Dalam usahatani istilah penerimaan sering disebut sebagai pendapatan kotor usahatani (grossfarm income) atau nilai produksi (value of production).
Besarnya penerimaan yang diterima oleh petani jeruk siam di Kamang Magek yaitu sebesar Rp Rp.57.904.000,- dan pendapatan bersih usahatani jeruk siam adalah penerimaan dikurangi dengan biaya-biaya yang dikeluarkan untuk usahatani jeruk siam selama 1 tahun sebesar Rp.35.926.917,-/tahun per luas lahan atau sebesar Rp.111.310.989,-/Ha. Data secara rinci mengenai penerimaan, biaya, pendapatan bersih usahatani jeruk siam dapat dilihat pada Tabel 5 berikut. 
Tabel 5. Penerimaan, Biaya, dan Pendapatan Bersih Petani Dalam Setahun Pada Usahatani Jeruk Siam di Kecamatan Kamang Magek

\begin{tabular}{|c|c|c|c|}
\hline No. & Uraian & Rata-rata/tahun & Rata-Rata/Tahun/Ha \\
\hline 1. & Produksi Jeruk $(\mathrm{Kg})$ & 5.264 & 15.131 \\
\hline 2. & Harga Jual (Rp) & 11.000 & 11.000 \\
\hline 3. & Penerimaan (Rp) & 57.904 .000 & 166.439 .593 \\
\hline 4. & Biaya Produksi & 21.977 .083 & 55.128 .604 \\
\hline . & Pendapatan Bersih (Rp) (3-4) & 35.926 .917 & 111.310 .989 \\
\hline
\end{tabular}

Pendapatan Rumah Tangga Petani dari Usahatani Lainnya

Ragam sumber pendapatan petani diduga dipengaruhi oleh tingkat pendapatan itu sendiri. Tingkat pendapatan yang rendah mengharuskan anggota rumah tangga untuk bekerja atau berusaha lebih giat untuk memenuhi kebutuhannya. Bagi sebagian rumah tangga, upaya tersebut tidak hanya menambah curahan jam kerja dari kegiatan yang ada, tetapi juga melakukan kegiatan atau usaha lain (Rahmi, 2016).

Tujuan pembangunan pertanian sebagai salah satu pembangunan ekonomi di Indonesia bertujuan memperbaiki dan meningkatkan kesejahteraan masyarakat dibidang usaha pertanian (Petani, nelayan dan peternak) di pedesaan. Hal ini dapat tercapai bila pendapatannya dapat ditingkatkan dari sumber pendapatannya baik dari pertanian maupun non pertanian. Sumber pendapatan masyarakat petani pedesaan berasal dari berbagai kegiatan yang secara garis besar dapat dikelompokkan menjadi industri, pengrajin, jasa angkutan dan sebagainya (Rahim dan Hastuti, 2007)

Pendapatan rumah tangga petani jeruk siam sebagian besar tidak berasal dari usahatani jeruk saja, tetapi pendapatan rumah tangga juga terdapat pada usahatani keluarga, seperti usahatani padi sawah, buncis dan jambu biji. Berdasarkan hasil penelitian diperoleh bahwa pendapatan dari usahatani lainnya diperoleh dari usahatani padi, buncis dan jambu biji.

Pendapatan para petani jeruk siam dari usahatani lainnya berupa penjualan dari hasil produksi dan ada sebagian yang digunakan untuk kebutuhan sendiri. Dari hasil penelitian diperoleh pendapatan rata-rata pertahun pada usahatani lainnya adalah sebesar Rp.4.969.259,- yang didapatkan dari total pendapatan di bagi dengan jumlah responden.

Pendapatan terbesar berasal dari padi sawah, hal ini menunjukkan bahwa petani di Kecamatan Kamang Magek selain menanam jeruk siam juga menanam tanaman padi. Hal ini karena kondisi lahan dan topografi wilayah Kamang Magek tadah hujan sehingga mendukung dalam bertani padi sawah.

Tabel 6. Pendapatan per Petani Selain Usahatani Jeruk Siam di Kecamatan Kamang Magek

\begin{tabular}{lll}
\hline No. & Pekerjaan & $\begin{array}{l}\text { Rata-Rata } \\
\text { Pendapatan/Tahun } \\
(\text { Rp) }\end{array}$ \\
\hline 1 & Padi & 4.796 .296 \\
2 & Jambu Biji & 107.407 \\
3 & Buncis & 65.556 \\
\hline & Jumlah & $\mathbf{4 . 9 6 9 . 2 5 9}$ \\
\hline
\end{tabular}

Untuk lebih jelasnya dapat dilihat pada Tabel 6.

\section{Pendapatan Rumah Tangga dari Non Usahatani}

Pada umumnya petani memperoleh pendapatan dari beberapa sumber. Hal ini dilakukan untuk mengetahui seberapa besar sumbangan atau kontribusi pendapatan yang diperoleh dari non usahatani. Bagi sebagian besar masyarakat perdesaan yang memiliki tingkat kontribusi pendapatan yang rendah dari sektor pertanian akan berupaya untuk meningkatkan pendapatannya dari luar sektor pertanian. Pendapatan responden dari sektor non usahatani bersumber dari PNS, buruh tani, kuli, dll. Dari hasil penelitian diperoleh pendapatan rata-rata pertahun pada usahatani lainnya adalah sebesar 
Rp.19.074.074,- yang didapatkan dari total pendapatan di bagi dengan jumlah responden. Untuk lebih jelasnya dapat dilihat pada Tabel 7.

Dari Tabel diatas dapat diketahui rata-rata pendapatan terbesar petani bersumber dari PNS yaitu sebesar Rp.10.888.889,- dan pendapatan terkecil bersumber dari penjaga sekolah sebesar Rp.111.111,- Hal ini dikarenakan sebagian besar petani responden bermata pencaharian sebagai PNS maupun kuli bangunan sebagai pekerjaan pokok maupun pekerjaan tambahan.

Tabel 7. Pendapatan per petani dari non usahatani selama satu tahun di Kecamatan Kamang Magek

\begin{tabular}{lll}
\hline No. & Uraian & $\begin{array}{l}\text { Rata-Rata } \\
\text { Pendapatan/Tahun }\end{array}$ \\
\hline 1 & Buruh Tani & 444.444 \\
2 & PNS & 10.888 .889 \\
3 & Sewa Angkot & 666.667 \\
4 & Perangkat & 1.733 .333 \\
5 & Nagari & 2.496 .296 \\
6 & Bamus & 600.000 \\
7 & Toko & 222.222 \\
8 & Motivator & 133.333 \\
9 & Kuli Bangunan & 1.777 .778 \\
10 & Penjaga Sekolah & 111.111 \\
\hline & Pendapatan & $\mathbf{1 9 . 0 7 4 . 0 7 4}$ \\
\hline
\end{tabular}

\section{Total Pendapatan Rumah Tangga Petani}

Kontribusi adalah sesuatu yang diberikan bersamasama dengan pihak lain dengan tujuan biaya, dan kerugian tertentu atau bersama. Kontribusi dapat berupa materi atau tindakan (Ahira, 2012). Secara garis besar terdapat tiga sumber pendapatan petani jeruk siam di Kecamatan Kamang Magek yaitu pendapatan dari usahatani jeruk siam, pendapatan selain usahatani jeruk siam dan pendapatan non usahatani. Hal ini untuk mengetahui berapa besar kontribusi tiap sumber pendapatan yang diperoleh petani. Sebagaimana yang disajikan dalam Tabel 8 berikut.

Berdasarkan dari Tabel 8 diketahui besarnya rata-rata total pendapatan rumah tangga petani yaitu sebesar Rp.51.321.011,- tahun dan kontribusi terbesar diperoleh dari usahatani jeruk siam yaitu sebesar 53,2\%. Total Pendapatan per bulan rumah tangga petani sebesaar Rp.4.276.751,-, jika dibandingkan dengan Upah Minimum Provinsi yang telah ditetapkan oleh pemerintah Tahun 2018 sebesar Rp.2.119.067,- per bulan, maka pendapatan yang diperoleh oleh petani tergolong tinggi karena melebihi dari UMP yang telah ditetapkan.

Besarnya kontribusi ini bisa menjadi tolak ukur bahwa sebagian besar petani menggantungkan hidupnya pada usahatani jeruk siam di Kecamatan Kamang Magek. Maka secara garis besar petani jeruk siam ini mampu untuk memenuhi kebutuhan keluarganya. Pendapatan usaha tersebut digunakan petani untuk memenuhi kebutuhan keluarga seperti biaya makan sehari-hari, biaya sek olah anak, dan lain-lain. Kontribusi yang besar menjadikan suatu usaha cocok untuk dikembangkan dengan kata lain juga dapat menarik petani lainnya untuk mengusahakan komoditi jeruk siam. Oleh karena itu

Tabel 8. Sumber-Sumber Pendapatan Petani Jeruk Siam Selama 1 Tahun Di Kecamatan Kamang Magek

\begin{tabular}{lllr}
\hline \multirow{2}{*}{ No. } & \multirow{2}{*}{ Pendapatan } & Kontribusi Pendapatan & \\
\cline { 3 - 4 } & & Jumlah (Rp) & Persentase (\%) \\
\hline 1. & Usahatani Jeruk Siam & 27.277 .678 & 53,20 \\
2. & Usahatani Selain Jeruk Siam & 4.969 .259 & 9,70 \\
3. & Diluar Usahatani/Sektor Lainnya & 19.074 .074 & 37,20 \\
\hline & Jumlah & $\mathbf{5 1 . 3 2 1 . 0 1 1}$ & $\mathbf{1 0 0}$ \\
\hline
\end{tabular}


dibutuhkan perhatian yang lebih oleh pemerintah dalam pengembangan usahatani jeruk siam di Kecamatan Kamang Magek. Pengembangan ini bisa dimulai pemerintah dengan meninjau kembali program perluasan lahan usahatani jeruk siam yang telah dicanangkan oleh Dinas Pertanian Tanaman Pangan Hortikultura dan Peternakan Agam pada tahun 2016 lalu.

\section{KESIMPULAN}

Pada hasil penelitian tentang Kontribusi Usahatani Jeruk Siam terhadap Pendapatan Rumah Tangga Petani di Kecamatan Kamang Magek, Kabupaten Agam,dapat disimpulkan sebagai berikut:

1. Petani responden yang melakukan usahatani jeruk siam rata-rata dengan pengalaman berusahatani antara 5-10 tahun serta $>10$ tahun dan penanaman jeruk dilakukan di lahan sendiri. Umur tanaman usahatani jeruk yang diusahakan yaitu 5 tahun dengan ratarata produksi $5.264 \mathrm{~kg}$ (Periode November 2017-Oktober 2018)

2. Rata-rata pendapatan petani selama satu tahun (November 2017 - Oktober 2018) yaitu sebesar Rp.27.277.678,- dengan kontribusi usahatani jeruk siam didapatkan sebesar 53,2\%. Sedangkan rata-rata pendapatan petani selain usahatani jeruk siam yaitu Rp.4.969.259,- dengan kontribusi sebesar $9,7 \%$. Serta pendapatan petani non usahatani yaitu sebesar Rp.19.074.074,dengan kontribusinya yaitu sebesar 37,2.

Dari uraian diatas saran yang dapat penulis berikan yaitu :

1. Budidaya usahatani jeruk siam ini cukup besar kontribusinya dan layak untuk dilakukan maka disarankan bagi pemerintah atau dinas pertanian disarankan agar dapat membantu petani dalam mengembangkan usahatani jeruk siam di Kecamatan Kamang Magek. Hal ini demi meningkatkan pendapatan petani serta agar masyarakat luas mengenal kembali jeruk siam di Kamang ini.

2. Untuk penelitian selanjutnya disarankan untuk melihat perbandingan pengaruh penerapan Standar Operasional Prosedur
(SOP) jeruk siam dengan tidak menerapkannya terhadap tingkat produksi jeruk siam.

\section{Daftar Pustaka}

Ahira, A. (2012). Deskripsi Teori Kontribusi. eprints.uny.ac.id

BPS. (2017). Kecamatan Kemang Magek Dalam Angka. Badan Pusat Statistik Kabupaten Agam, Lubuk Basung.

Gustiyana, H. (2004). Analisis Pendapatan Usahatani untuk Produk Pertanian Salemba Empat. Jakarta: Salemba Empat.

Pratama, D. (2010). Pengertian Hortikultura. Dodipratama.Blogspot.com.

Purnama, H. (2009). Strategi Pemasaran Agrowisata Kebun Buah Plantera Fruit Paradise Kabupaten kendal Jawa Tengah. skripsi, Institut Pertanian Bogor, Fakultas Ekonomi Dan Manajemen, Bogor.

Rahim dan Hastuti. (2007). Pengantar teori dan Kasus Ekonomika Pertanian. Jakarta: Penebar Swadaya.

Rahmi, A. (2016). Analisis Kontribusi Pendapatan Petani Jeruk Terhadap Pendapatan Rumah Tangga Petani di Kanagarian Pekonina Kecamatan Pauh Duo Kabupaten Solok Selatan. skripsi, Universitas Andalas, Fakultas Pertanian.

Soedarya , A. (2009). Agribisnis Jeruk. Bandung: CV Pustaka Grafika.

Soekartawi. (2006). Analisis Usahatani. Jakarta: UI Press. 